\title{
Pengembangan Layanan Bimbingan dan Konseling Komprehensif di Sekolah Dasar
}

\author{
Ulfa Ayu Hanifah \\ Prodi Pendidikan Fisika,Fakultas Matematika dan Ilmu Pengetahuan Alam \\ Universitas Negeri Padang,Email : ulfaahn30@gmail.com
}

\section{ABSTRAK}

Sekolah merupakan wadah dimana seorang individu dididik dan ditempah berlandaskan ilmu pengetahuan yang didapat setelah pengajaran dari orang tua. Sekolah menjadi rumah kedua bagi seorang individu untuk dapat menjangkau dunia lebih luas yang kemudian menjadi batu loncatan untuk merancang masa depan. Perkembangan dunia yang kian pesat penuh dengan beragam metode serta teknologi baru menuntut peran guru dan sekolah lebih ekstra. Adanya perubahan sistim dunia pendidikan yang berubah menimbulkan kesenjangan terutama bagi guru,sekolah, bahkan peserta didik. Kondisi yang sangat mengkhawatirkan dalam fase perkembangan yaitu pada masa remaja dimana remaja saat ini memiliki tingkat emosional yang berubah-ubah terhadap orang disekitarnya, tidak suka digurui, diperintah maupun diabaikan. Dengan begitu, peranan bimbingan dan konseling di dunia pendidikan sangat dibutuhkan,tanpa terkecuali di lingkungan sekolah. Maka dari itu, penelitian ini berisi bagaiman pelayanan bimbingan dan konseling di sekolah. Metode penelitian yang digunakan yaitu metode deskriptif yang dimana berisi tentang deskripsi pelayanan bimbingan konseling di lingkungan sekolah. Hasil penelitian berdasarkan metode yang dilakukan menunjukkan banyak sekolah yang telah menerapkan dengan baik pelayanan bimbingan dan konseling sebagai sarana perkembangan pendidikan agar tercapai tujuan pendidikan yang diinginkan.

Kata kunci : Pelayanan, Komprehensif,dan Bimbingan Konseling

\section{PENDAHULUAN}

Pendidikan di Indonesia kian hari

kian berkembang pesat. Banyak perubahan yang signifikan dari zaman ke zaman. Ditambah pula dengan gejolak dunia globalisasi dengan penuh teknologi terbaru yang mendorong pendidikan juga harus lebih baik. Dengan perkembangan teknologi yang kian beragam inilah menimbulkan kesenjangan, baik dibidang ekonomi, sosial, budaya, dan bahkan pada individu nya sendiri. Hal ini menimbulkan stigma baru di dunia pendidikan,dimana pendidikan akan berjalan sesuai dengan tujuan pendidikan yang diinginkan salah satu nya melalui peserta didik nya.
Sekolah menyediakan sebuah layanan bimbingan bagi para peserta didiknya. Layanan ini menjadi centre dalam dunia pendidikan, yatitu layanan bimbingan konseling. Layanan bimbingan konseling ini merupakan suatu wadah dimana peserta didik dapat menuangkan berbagai permasalahan yang kemudian dipecahkan dengan bantuan dan bimbingan guru bimbingan konseling. Bimbingan konseling di sekolah menjadi garda terdepan dalam pengoptimalan perkembangan peserta didik. Peserta didik menjadi sasaran terdepan dalam layanan bimbingan konseling. Layanan ini tak terlepas dari kurikulum sekarang, yaitu kurikulum 2013. Dalam kurikulum 2013 memuat berbagai pilihan peserta 
didik yang sesuai dengan potensi dan kemampuan siswa.

Kehadiran layanan bimbingan konseling di sekolah saat ini saat dibutuhkan. Terlepas dari bagaimana siswa dapat menentukan pilihan dari kemampuannya, bimbingan konseling juga menjadi sarana pemecahan solusi masalah yang berkaitan dengan diri peserta didik. Dengan begitu harapan akan pencapaian tujuan pendidikan dapat dimaksimalkan dengan baik. Pelaksanaan layanan BK di sekolah dilaksanakan oleh guru bimbingan dan konseling (konselor).

Konselor sebagaimana diatur dalam undang-undang dinyatakan sebagai salah satu kualifikasi pendidik, sejajar dengan kualifikasi guru, dosen, pamong belajar, tutor, widyaiswara, fasilitator, dan instruktur (UU No.20 Tahun 2003 Pasal 1 Ayat 6). Lampiran Peraturan Menteri Pendidikan Nasional No. 27 tahun 2008 tentang Standar Kualifikasi Akademik dan Kompetensi Konselor bahwa sosok utuh kompetensi konselor mencakup kompetensi akademik dan profesional sebagai keutuhan, kompetensi akademik merupakan landasan ilmiah dari pelaksanaan pelayanan profesional bimbingan dan konseling. Kompetensi Profesional menyatakan bahwa menguasai konsep dan praksis asesmen untuk memahami kondisi, kebutuhan, dan masalah konseling (Permendiknas No.27 Tahun 2008).

\section{DISKUSI}

Bimbingan dan konseling adalah sebuah wadah dimana terdapat hubungan erat antara guru,sekolah,dan juga peserta didik. Bimbingan dan konseling adalah upaya layanan pemberian bantuan dan dukungan kepada seorang individu agar dapat mencapai tujuan pembelajaran yang optimal. Dalam Peraturan Permerintah
No. 29 Tahun 1990 tentang Pendidikan Menengah Pasal 27 Ayat 1 bahwa bimbingan merupakan bantuan yang diberikan kepada siswa dalam rangka upaya menemukan pribadi, mengenal lingkungan dan merencanakan masa depan.

Menurut Surat Keputusan Mendikbud No. 025/1995 tentang Petunjuk Pelaksanaan Jabatan Fungsional Guru dan Angka Kreditnya, menyebutkan bahwa Bimbingan dan Konseling (BK) adalah layanan bantuan untuk peserta didik, baik secara perorangan maupun kelompok, agar mandiri dan berkembang secara optimal, dalam bimbingan pribadi, bimbingan sosial, bimbingan belajar dan bimbingan karir, melalui berbagai jenis layanan dan kegiatan pendukung berdasarkan norma-norma yang berlaku.

Selain pengertian tersebut, juga terdapat beberapa pengertian bimbingan konseling menurut beberapa sumber buku. Menurut Azzet (2013:11), bimbingan konseling adalah upaya pemberian bantuan kepada anak didik agar dapat memahami dirinya sehingga sanggup mengarahkan diri dan bertindak dengan baik sesuai dengan perkembangan jiwanya. Upaya ini dilakukan secara sistematis dan berkesinambungan. Di lain buku Prayetno,dkk (2004:2) memaparkan bahwa bimbingan dan konseling adalah pelayanan bantuan untuk peserta didik,baik secara perorangan maupun kelompok agar mandiri dan berkembang secara optimal,dalam bimbingan pribadi,bimbingan sosial,bimbingan belajar, dan bimbingan karir,berdasarkan norma-norma yang berlaku.

Permendikbud Nomor 111 Tahun 2014 tentang Bimbingan dan Konseling Pada Pendidikan Dasar dan Pendidikan Menengah menjadi kunci keberhasilan 
penyelenggaraan bimbingan dan konseling sekolah di Indonesia. Permendikbud ini dimaksudkan memberikan arah penyelenggaraan bimbingan dan sekolah dalam implementasi kurikulum 2013. Meskipun secara eksplisit tidak menyebutkan bimbingan dan konseling komprehensif, namun komponen layanan bimbingan dan koseling diadaptasi dari konsep bimbingan dan konseling komprehensif.

Pada dasarnya, layanan bimbingan konseling adalah suatu kegiatan bimbingan konseling yang dilakukan melalui kontak langsung dengan peserta didik atau konseli yang berhubungan langsung dengan permasalahan yang dihadapinya. Kegiatan yang merupakan layanan bimbingan konseling mengemban fungsi tertentu dan pemenuhan fungsi tersebut diharapkan dapat dirasakan oleh sasaran layanan secara langsung.

Terdapat salah satu model dalam bimbingan dan konseling yang berimplementasi langsung terhadap tujuan yang menjadi dasar pencapaian, yang dikenal sebagai layanan bimbingan dan konseling komprehensif. Pengertian Komprehensif dalam KBBI adalah meiliki wawasan yang luas serta mampu menerima dengan baik. Dapat ditarik kesimpulan bahwa layanan bimbingan dan konseling Komprehensif ini merupakan suatu alternatif model bimbingan konseling yang menggabungkan subjek-subjek Bimbingan Konseling baik siswa, orang tua, guru dan staf administrasi serta seluruh anggota masyarakat untuk meningkatkan layanan bimbingan dan konseling di sekolah.

Layanan bimbingan dan konseling komprehensif berpengaruh besar dalam mengembangkan self knowledge pada anak sekolah dasar. Pada dasarnya anak-anak di sekolah dasar memiliki tugas perkembangan dalam pemahaman akan dirinya atau self knowledge yaitu pada taraf pengetahuan tentang pentingnya konsep diri, keterampilan untuk berinteraksi dengan orang lain, dan kesadaran akan pentingnya pertumbuhan dan perubahan (Cobia dan Hendrason,2013).

Layanan bimbingan dan konseling didasarkan atas PP Nomor 28 tahun 1990, Bab X pasal 2 ayat (1) yang menyatakan bimbingan merupakan bantuan yang diberikan kepada siswa dalam upaya menemukan pribadi, mengenal lingkungan dan merancang masa depan (Furqon,2005). Pada Permendikbud Nomor 111 tahun 2014 tentang Bimbingan dan Konseling pada Pendidikan Dasar dan Pendidikan Menengah pada pasal 10 ayat (1) juga menegaskan bahwa "penyelenggaraan Bimbingan dan Konseling pada SD/MI atau yang sederajat dilakukan oleh Konselor atau Guru Bimbingan dan Konseling ".

Dalam pengembangan program layanan bimbingan dan konseling komprehensif di sekolah dasar menurut Gibson, \& Morse \& Russell (Schmidt, 2013) meliputi konseling, konsultasi , koordinasi, dan penilaian layanan untuk siswa, orang tua, dan guru. Morse \& Russell (1988). Pada hakikat nya menurut Morse dan Russell (1998) konselor di sekolah dasar bertugas memberikan layanan kelompok dengan siswa untuk mengarahkan serta membatu peserta didik memecahkan permasalahan. Dilain hal menurut Furqon (2005) pengembangan layanan bimbingan konseling komprehensif di sekolah dasar, harus memperhatikan tugas perkembangan siswa sekolah dasar yaitu : Mempelajari keterampilan fisik yang diperlukan untuk bermain, membangun sikap yang sehat mengenai diri sendiri sebagai makhluk yangs sedang tumbuh, belajar menyesuikan diri dengan teman sebaya, mulai mengembangkan peran sosial sebagai wanita atau pria, mengembangkan keterampilan keterampilan dasar untuk membaca, 
menulis dan berhitung, mengembangkan pengertian-pengertian yang diperlukan dalam kehidupan sehari-hari, mengembangkan kata hati, moral, dan nilai- nilai, dan mencapai kebebasan pribadi.

Terdapat pula prinsip-prinsip dari layanan bimbingan dan konseling komprehensif ini, dikemukakan oleh Bhakti (2017) tentang prinsip-prinsip 1) Subjek layanan adalah semua peserta didik; 2) fokus pada kegiatan pembelajaran peserta didik dan mendorong perkembangan peserta didik; 3) konselor dan guru merupakan fungsionaris yang bekerja sama; 4) program bimbingan terorganisir dan terencana sebagai bagian vital dari bimbingan komprehensif; 5) peduli kepada penerimaan diri, pemahaman diri, dan peningkatan diri; 6) memfokuskan pada proses; 7) berorientasi taem work dan mensyaratkan pelayanan dari konselor profesional yang terlatih; 8) bersifat fleksibel dan sekuensial.

Cobia dan henderson menjelaskan kembali mengenai model bimbingan dan konseling komprehensif yang dimana terdapat tiga unsur dan empat komponen. Berdasarkan tiga unsur ini meliputi isi dari program, kerangka yang organisatoris, dan sumber daya. Isi meliputi kemampuan siswa. Kerangka mempunyai tiga komponen struktural (definisi, asumsi, dan dasar pemikiran) dan empat komponen program (guidance curriculum, individual planning, responsive services, and system support). Unsur sumber daya menyertakan personil, anggaran dana, dan mengimplementasikan program. Bimbingan dan konseling komprehensif mempunyai komponen yang menyertakan aktivitas dan tanggungjawab dari semua yang terlibat dalam program bimbingan dan konseling komprehensif.

\section{DAFTAR PUSTAKA}

Azzet, Akhmad Muhaimin. 2013. Bimbingan \& Konseling di Sekolah. Jogjakarta: Ar-Ruzz Media.

Bhakti, C. P. (2017). Program bimbingan dan konseling komprehensif untuk mengembangkan standar kompetensi siswa. Jurkam: Jurnal Konseling Andi Matappa, 1(2), 131-132.

Cobia, D. C., \& Henderson, D. A. (2003). Handbook of school counseling. Prentice Hall.

Depdiknas. 2008. Penataan Pendidikan Profesional Konselor dan Layanan Bimbingan dan Konseling Dalam Jalur Pendidikan Formal. Jakarta : Depdiknas.

Furqon. 2005. Konsep dan Aplikasi Bimbingan dan Konseling untuk Sekolah Dasar. Bandung : Pustaka Bani Quraisy

Hallen, A. 2002. Bimbingan dan Konseling. Jakarta: Ciputat Pers

Hikmawati, F. (2016). Bimbingan dan Konseling. Rajawali Press.

Kamaluddin, H. (2011). Bimbingan dan Konseling Sekolah. Jurnal Pendidikan dan Kebudayaan, 17(4), 447-454.

Nurhayati, E. (2018). Bimbingan, Konseling, dan Psikoterapi Inovatif(Vol. 2). Pustaka Pelajar.

Prayetno dkk. 2004. Pedoman Khusus Bimbingan dan Konseling. Jakarta: Depdiknas.

Schmidt, J. J. (2013). Counseling in schools: Comprehensive programs of responsive services for all students. Pearson Higher Ed. 